\title{
Good Corporate Governance and Predicting Financial Distress Using Logistic and Probit Regression Model
}

\author{
Juniarti \\ Faculty of Economics, Petra Christian University \\ yunie@peter.petra.ac.id
}

\begin{abstract}
The study aims to prove whether good corporate governance (GCG) is able to predict the probability of companies experiencing financial difficulties. Financial ratios that traditionally used for predicting bankruptcy remains used in this study. Besides, this study also compares logit and probit regression models, which are widely used in research related accounting bankruptcy prediction. Both models will be compared to determine which model is more superior. The sample in this study is the infrastructure, transportation, utilities \& trade, services and hotels companies experiencing financial distress in the period 2008-2011. The results show that GCG and other three variables control i.e DTA, CR and company category do not prove significantly to predict the probability of companies experiencing financial difficulties. NPM, the only variable that proved significantly distinguishing healthy firms and distress. In general, logit and probit models do not result in different conclusions. Both of the models confirm the goodness of fit of models and the results of hypothesis testing. In terms of classification accuracy, logit model proves more accurate predictions than the probit models.
\end{abstract}

Keywords: good corporate governance, financial distress, financial ratio, logistic regression, probit regression

\section{INTRODUCTION}

Implementation of GCG consistently will support firm's performance and reduce the likelihood of financial distress. Fich \& Slezak (2007) and Daily \& Dalton (1994) proved that the implementation of GCG kept companies from financial distress and made companies sustain. Sulistyanto and Prapti (2003) found that companies which implement GCG consistently also enjoy a positive response from their investors and creditors. Companies' images are also contributed by GCG implementation.

McKinsey in one of its survey conducted jointly with the World Bank, Park and Institutional Investor Magazine in 2000 (in Coombes \& Watson, 2000), revealed that companies which implement a high standard of CGC will further attract investors and keep them in the capital market. Investors believed that their investment will be protected in well-managed companies. Investor trust will have a positive impact on the availability of working capital, while creditor confidence will impact on the decrease of cost of debt (Ashbaugh et.al, 2004; Byun, 2007; Bhojraj \& Sengupta, 2003). Furthermore, Elloumi \& Gueyie (2001); Supatmi (2007); Huang \& Zhao, (2008);
Fich \& Slezak (2008); Ward \& Foster (1997), Yin \& Tsui (2004) and Sengupta \& Faccio (2011) proved that the probability of financial difficulties of implementing GCG, is lower than companies that do not implement GCG.

Most research in prediction of financially distress companies usually used financial ratios as predictor variables. On the other hand, the implementation of GCG which has more than a decade in Indonesia needs to be empirically proven its benefits to the company, especially its role in saving the company from financial difficulties. Therefore the purpose of this research is to observe the role of corporate governance in predicting the likelihood of companies experiencing financial distress.

Another aim of this article is to compare two regression models namely logistic and probit regression, to see whether logit or probit model is actually better to predict, since the two models widely used in accounting research. Logit model uses the cumulative logistic function (logistic CDF), while the probit model uses the normal CDF. Theoretically, the difference between the two models lies in the tail of the curve, where the curve probit (normal CDF) reaches the axes more quickly than the logit curve (logistic CDF). In practice, the 
choice of probit or logit models lies in the convenience of mathematical calculation and availability of application programs. Based on the two issues above, logit is generally preferred over probit (Gujarati 2004).

\section{Financial Distress (FD)}

Financial distress is the result of deterioration in a company's business, which can be caused by several factors, such as poor management, unwise expansion, fierce competition, too much debt, court lawsuit and unfavorable contracts (Emery, Finnerty \& Stowe 2007). Meanwhile, Hofer (1980) and Whitaker (1999) defined financial distress as a condition in which company had negative net income for several consecutive years. While Almilia (2004) defined financial distress as a condition experienced delisted due to negative net income and book value of equity. According to Plat and Plat (2002), financial distress is as a step decrease in financial condition that occurred prior to the bankruptcy or liquidation. In this study, companies are grouped as experiencing financial distress if it has negative retained earnings and net income during the two sequential years.

\section{Good Corporate Governance}

Corporate governance is important to shareholders due to the existing of the information asymmetry in which shareholders cannot directly observe the actions of management thus potentially creating problems of moral hazard and adverse selection (Ashbaugh, et al. 2004). Corporate governance represents a set of mechanisms aimed to reduce agency costs resulting from the existence of information asymmetry. Attribute indicates that the company is implementing good corporate governance can be seen from an organizational structure that accommodates oversight mechanisms accountable, transparent and impartial. The existence of the independent board of commissioners, audit committees, and institutional ownership is seen as a positive attribute that would secure the interests of both shareholders and other stakeholders.

In this study, the application of GCG is measured by determining the score, similar with FCGI method, the difference lies in the aspects assessed. GCG assessed from three aspects: the board, audit committee and ownership structure. The weight to the third aspect considered the results of previous studies that prove that the structure of ownership, both institutional and managerial has a significant influence on the level of supervision and performance management. Furthermore, GCG score is calculated based on the value of every aspect of GCG by the following formula.

GCG score $=\left[\left(\frac{O S}{T O S} \times 40 \%\right)+\left(\frac{B D}{T B D} \times 35 \%\right)+\left(\frac{A C}{T A C} \times 25 \%\right)\right]$

where:

OS : ownership sructure score

TOS : overall ownership structure score

BD : board of directors score

TBD : overall score of board of directors

$\mathrm{AC}$ : audit committee score

TAC : overall audit committee score

\section{Financial Ratio}

According to Brigham and Daves (2003), signs of potential financial distress were usually apparent in the financial ratio long before the company actually failed. Researchers, generally used this ratio to predict the probability of a company going bankrupt. Financial ratios used in this study is selected based on results from previous studies in which financial ratios have been proven consistently as the predictor variables. There are three financial ratios using in this study. Net profit margin is to measure the profitability for the company. It measures the efficiency from the use of company assets and manages its operations. Net profit margin is defined as follows:

Net Profit Margin $=\frac{\text { Net Income }}{\text { Sales }}$

Net profit margin is very useful for comparing the performance of companies within the same industry. High net profit margins indicate a company has better control over costs than its competitors.

Current ratio is the ratio used to measure a company's ability to pay its short-term liabilities with current assets. Current ratio is defined as follows:

Current Ratio $=\frac{\text { Current Assets }}{\text { Current Liabilities }}$

A high current ratio indicates a good liquidity, means a better guarantee on short-term debt. But if it is too high, the effect on earning power is also not good, because not all working capital utilized but also indicates a lack of efficiency in the use of cash and other current assets (Ross, Westerfield, and Jordan 2008).

Debt to the asset ratio is a ratio used to measure how much of the company's assets funded by debt. Debt to the asset ratio is defined as follows: 
Debt Asset Ratio $=\frac{\text { Total Debt }}{\text { Total Asset }}$

The higher this ratio, the greater the amount of debt used to generate profit and the higher level of debt and financial leverage. If the ratio is above 1, meaning that all assets funded by debt, and would be quite harmful to the company if the loan is due (Gitman 2009).

\section{Hypothesis}

GCG score indicates the level of implementation of GCG in an enterprise. The higher the score GCG means the BOC function; the Audit Committee and Ownership Structure have done a good job so that opportunities to commit fraud management will be minimized. It leads company to achieve its goal, enable to create positive net income and retained earnings, in turn allows a company to avoid financial distress. Gompers, et al (2003) found that companies which implement GCG will experience increased performance. Daniri in Nuswandari (2009) found that the implementation of good corporate governance can reduce the likelihood of financial distress. Therefore, the hypothesis is:

$\mathrm{H}_{1}$ : The higher the GCG score, the lower the possibility of companies experiencing financial distress.

Net Profit Margin Ratio is used to calculate the extent to which the company's ability to generate net income in certain sales levels (Bastian $\&$ Suhardjono, 2006). The higher this ratio showed an increase in sales of the company is greater than the expenses incurred. It enables a company to keep positive net income and retained earnings so that the likelihood of financial distress is reduced. Based on the above, the second hypothesis can be stated as follows:

$\mathrm{H}_{2}$ : The higher the NPM ratio, the less likely the company experienced financial distress.

Almilia (2004) showed that the ratio of DTA has a positive and significant impact on financial distress, meaning that the higher the ratio the more likely DTA companies experiencing financial distress. Iramani (2008) also concluded similar results where the DTA significant effect on financial distress and prove that DTA companies experiencing financial distress is higher than healthy companies. Based on the above, the third hypothesis can be stated as follows:

$\mathrm{H}_{3}$ : The higher Debt to Total Assets Ratio, the more likely the company experienced financial distress.
Companies that have a low current ratio less than one means the companies' current assets are insufficient to meet short-term obligations maturing; therefore, the possibility to experience financial difficulties is greater than a company that has a high current ratio. Several studies have shown that the current ratio negatively affected the financial distress and can be used to predict the financial distress of a company. The studies include research by Almilia and Kristijadi (2003); Beaver (1966) the Platt and Platt (2002). Based on the above, the fourth hypothesis is proposed:

$\mathrm{H}_{4}$ : The higher the current ratio, the less likely the companies experienced financial distress.

In this study, samples are also categorized by industry groups namely (1) the business sector of infrastructure, transportation and utilities as category 1 and (2) the business sector trade, services and investment as category 2. To see whether the industrial sector can differentiate whether the company will experience financial distress or not, then proposed the following hypothesis.

$\mathrm{H}_{5}$ : The industry group was able to distinguish the possibility of companies experiencing financial distress.

\section{RESEARCH METHODS}

\section{Model Analysis}

Model analysis used to predict financial distress based on the above hypotheses, is formulized as follows:

Logit model of equation is: $\mathrm{Ln} \mathrm{P} /(1-\mathrm{P})=\mathrm{B}_{0}-\mathrm{B}_{1} \mathrm{GCG}-\mathrm{B}_{2} \mathrm{NPM}+\mathrm{B}_{3} \mathrm{DTA}-\mathrm{B}_{4} \mathrm{DTA}-$

$B_{5}$ Cateogory $+u_{j}$

While probit model of equation is:

$\mathrm{p}=\Phi\left(\mathrm{B}_{0}-\mathrm{B}_{1} \mathrm{GCG}-\mathrm{B}_{2} \mathrm{NPM}+\mathrm{B}_{3} \mathrm{DTA}-\mathrm{B}_{4} \mathrm{CR}-\right.$

$B_{5}$ Category $\left.+u_{j}\right)$

This study analyzed the relationship between these variables. The definition of each is as follows

a. Financial distress: a company categorized as financial distress company, if it has the Negative Negative Net Income and Retained Earnings. Companies included in the category of financial distress given code (1) and code (0) is for healthy companies.

b. GCG is proxied by the board of directors, audit committee and ownership structure. 
Board of director is measured by:

- Composition of board of commissioners of the board of director;

- Number of independent board of directors.

Audit committee is measured by:

- Composition of independent audit committee of total audit committee.

- The number of audit committee;

- The competency of audit committee.

Ownership structure is measured by:

- The portion of managerial ownership;

- The portion of institutional ownership.

Each measure is given point 1 if it is met, if not met, then given 0 points. To obtain a total score of GCG, then used the formula:

GCG score $=\left[\left(\frac{O S}{T O S} \times 40 \%\right)+\left(\frac{B D}{T B D} \times 35 \%\right)+\left(\frac{A C}{T A C} \times 25 \%\right)\right]$

c. NPM: portion of net income to total sales.

d. DTA: portion of debt to total asset

e. CR: portion of current asset to current liabilities.

f. Category: industrial sector, $1=$ infrastructure, transportation and utility, $2=$ commercial, services and hotel.

\section{Research Sample}

The sample for this study is a company experiencing financial distress during the period 2008-2011, in infrastructure, transportation and utilities' sector and trade, services and hotels' sector. The numbers of eligible companies are 111 companies. To determine the status of the company into a state of financial distress or not, is used the following two criteria: companies have a negative net income and retained earnings during two consecutive years. This study only uses the data one year before the company experiencing financial distress. Current year data is used to predict one year ahead of data.

\section{RESULTS AND DISCUSSION}

\section{Descriptive Statistic}

The hypotheses are tested using logistic and probit regression. The use of the two statistical tests is to find out which method is more accurate to test the hypothesis. There are 111 eligible companies, 100 companies are used as samples and selected using random sampling, the remainder will be used to test the accuracy of the model. Based on 100 samples selected, descriptive statistical is analyzed, and found that there are some extreme values of $\mathrm{CR}$ compared to the average value of $\mathrm{CR}$ of sample company. To reduce the potentially disturbing results, then companies that have an extreme value of $\mathrm{CR}$ are excluded from testing. There are four companies that are not included in the testing due to the extreme value of $\mathrm{CR}$, and one company with NPM extreme value is also excluded from the sample, so the number of samples remaining 95 companies consisting of 64 healthy companies and 31 unhealthy companies. Descriptive statistical runs once again after all samples with extreme values are excluded, results as shown in Table 1.

There is no difference mean GCG'scores between healthy and unhealthy companies. On average, GCG scores of all sample companies are high, that is 0.59 from the highest score 1 . The NPM ratio for the unhealthy companies shows negative numbers, while the average NPM of healthy companies is positive albeit small. The ratio DTA of the unhealthy companies slightly higher compared with healthy companies, although in general average DTA ratio is quite high, that is 0.566. Meanwhile, the average value of the CR of group healthy and unhealthy companies do not differ much and the mean of $\mathrm{CR}$ of entire sample firms is quite high.

Table 1. Descriptive Statistic

\begin{tabular}{|l|r|r|r|r|r|}
\hline & FD & Min & Max & Mean & Std Dev \\
\hline GCG & 0 & 0.2500 & 1.0000 & 0.5964 & 0.1743 \\
\hline & 1 & 0.2000 & 0.8250 & 0.5818 & 0.1425 \\
\hline NPM & all & 0.2000 & 1.0000 & 0.5911 & 0.1654 \\
\hline & 0 & -1.7212 & 0.7473 & 0.0366 & 0.2580 \\
\hline & 1 & -1.8865 & 0.1803 & -0.1912 & 0.4780 \\
\hline DTA & all & -1.8865 & 0.7473 & -0.4540 & 0.3529 \\
\hline & 0 & 0.0500 & 0.9123 & 0.5013 & 0.2129 \\
\hline & 1 & 0.0400 & 2.2005 & 0.6863 & 0.4380 \\
\hline CR & all & 0.0400 & 2.2005 & 0.5660 & 0.3046 \\
\hline & 0 & 0.0800 & 6.7420 & 1.8530 & 1.4490 \\
\hline & 1 & 0.0621 & 4.1420 & 1.3700 & 1.0700 \\
\hline & all & 0.0621 & 6.7420 & 1.7007 & 1.3531 \\
\hline
\end{tabular}

\section{Goodness of fit}

Prior to further analyze and interpret the test results, it is important to know the goodness of fit of the model predictions.

Table 1. Sumarry of Goodness of Fit (p-value in parantheses)

\begin{tabular}{|c|c|c|}
\hline & $\begin{array}{c}\text { Logitistic } \\
\text { Regression }\end{array}$ & $\begin{array}{c}\text { Probit } \\
\text { Regression }\end{array}$ \\
\hline Log-likelihood & $\begin{array}{r}-51.964 \\
(0.007)\end{array}$ & $\begin{array}{r}-52.173 \\
(0.008)\end{array}$ \\
\hline Hosmer-Lemeshow & $\begin{array}{r}4.14 \\
(0.844)\end{array}$ & $\begin{array}{r}10.281 \\
(0.246)\end{array}$ \\
\hline
\end{tabular}

Logistic regression model shows the loglikelihood of -51,964 with p-value 0007, significance 
under $a=0.05$ means the model fit. The accuracy test of models can also use the Hosmer and Lemeshow Test. Unlike the common goodness of fit test, in Hosmer and Lemeshow Test, to see if the empirical data conform to the model, the value of the Hosmer-Lemeshow p must be above 0.05 (for $a=0.05)$. In this test Hosmer-Lemeshow 4.140 with the p-value $0844>$ of 0.05 indicates that the model fit.

Test the feasibility of using probit regression models shows almost the same results with preceding model, ie log-likelihood $-52,173$ with the p-value $=0.008$, means model fit, while the Hosmer-Lemeshow shows 10.181 with the p-value $=0.2486$, above 0.05 confirms that the feasibility of this model is met.

\section{Results of Hypothesis Test}

Summary of test results using logistic and probit regression (Table 2), shows consistent results, although the figures of the estimated parameters are different.

Table 2. The estimated parameters (standard error and p-value in parentheses)

\begin{tabular}{|c|c|c|}
\hline & $\begin{array}{c}\text { Logistic } \\
\text { Regression }\end{array}$ & $\begin{array}{c}\text { Probit } \\
\text { Regession }\end{array}$ \\
\hline \multicolumn{3}{|l|}{ Predictor } \\
\hline \multirow[t]{3}{*}{ Constant } & 0.1753 & 0.03580 \\
\hline & (1.5426) & (0.9082) \\
\hline & $(0.910)$ & (0.969) \\
\hline \multirow[t]{3}{*}{ GCG } & -1.5605 & -0.8046 \\
\hline & (1.7307) & (1.002) \\
\hline & $(0.367)$ & $(0.422)$ \\
\hline \multirow[t]{3}{*}{ NPM } & -2.4159 & -1.1988 \\
\hline & (1.0910) & $(0.0535)$ \\
\hline & (0.027) & $(0.025)$ \\
\hline \multirow[t]{3}{*}{ DTA } & 1.37360 & 0.7639 \\
\hline & $(0.8881)$ & (0.5109) \\
\hline & $(0.122)$ & $(0.135)$ \\
\hline \multirow[t]{3}{*}{ CR } & -0.3127 & -0.2025 \\
\hline & $(0.243)$ & $(0.1485)$ \\
\hline & $(0.2680)$ & $(0.173)$ \\
\hline \multirow[t]{3}{*}{ Kategori (2) } & -0.5556 & -0.2844 \\
\hline & $(0.6278)$ & $(0.3667)$ \\
\hline & $(0.376)$ & $(0.438)$ \\
\hline *) signifikan & $=0.05$ & \\
\hline
\end{tabular}

To compare the results of the two models above, Amemiya (in Gujarati 2004), suggested to multiply the logit parameter estimates by 0.625 so the estimated parameter will closer with the estimated logit. However, because the two models give consistent results, though the numbers of estimated parameters are different, then the suggestion of Amemiya is not necessary.

Table 2 shows that of the five proposed hypotheses, only hypothesis 2 is proven, the higher the NPM ratio the less likely the firm will experience financial distress, NPM coefficient significant at $\alpha=0.05$. These results were consistent in both models either logit or probit. The four other hypothesis is not proven significantly to predict the likelihood of companies experiencing financial distress. All coefficients either logit or probit produce direction according to the relationship hypothesized.

GCG variable is not able to predict the likelihood of companies experiencing financial distress, because the average score GCG between healthy companies and distress did not differ much (Table 1). Companies are classified as unhealthy GCG proved to have a high enough score the same as a healthy company. Sylvia and Siddharta (2005) suggest that the implementation of good corporate governance in Indonesia is only done to comply with any formal or regulation but not to enforce GCG in the company. Besides that mechanisms of an organizational structure is not ineffective oversight function, so that the high corporate governance scores have no effect on the performance of the organization and the possibility of being healthy or unhealthy organization.

Coefficient of DTA using logit and probit is 1.37360 and 0.7639 consecutively (Table 2 ) fit the relationship predicted, that is positively related to corporate financial difficulty, unfortunately the coefficient is not significant. DTA mean for healthy firms is lower than the unhealthy firms, but it does not sharply differ with the mean across the sample DTA, that is 0.5660 (Table 1). Kasmir (2008) stated that the ratio of DTA healthy companies is under $35 \%$, whereas this research shows that the DTA ratio of healthy company exceeds $35 \%$, and not too different from the unhealthy company. That is why the DTA does not significantly predict the probability of healthy and unhealthy companies. Research by Almilia and Kristijadi (2003) and Widarjo and Setiawan (2009) also failed to prove the DTA effect on the possibility of firms experiencing financial distress

Current ratio (CR), is also not able to predict whether the company experiencing financial distress or not. Although resulting coefficient fits the relationship predicted. CR profiles which are categorized as healthy and unhealthy indicate numbers that are not too different, even the CR ratio unhealthy companies still above one (Table 1), meaning that on average companies in the unhealthy group are not experiencing liquidity problems. This is reasonable because these companies should provide sufficient short-term funds, in order to remain able to sustain its operations. It is intended to delay the threat of bankruptcy or dissolved. 
Moreover, opportunities to experience financial difficulties do not differ among the industrial sector. It is evident that the coefficient is not significant using either logit or probit models.

\section{Accuracy Classification Test (in sample and out sample)}

Logit and probit equation model obtained from previous testing, both models have met the feasibility of this model, as in the analysis in the above section. To find out which model is better, then the model equations applied to the samples tested and compared with empirical data (in samples and out sample).

Logit model of equation is:

$\mathrm{Ln} \mathrm{P} /(1-\mathrm{P})=0.1753-1.5605 \mathrm{GCG}-2.4159 \mathrm{NPM}+$ 1.37360DTA - 0.3127DTA - 0.5556 Kategori

While probit model of equation is: $\mathrm{p}=\Phi(0.03580-0.8046 \mathrm{GCG}-1.1988 \mathrm{NPM}+$ 0.7639DTA - 0.2025CR - 0.2844 Kategori)

\section{In sample}

In this section, the model logit and probit equations applied to the data to test the 95 eligible data, the sample group consisted of 64 healthy companies and 31 sample groups of distress (unhealthy). The results are presented in tables 3 and 4, respectively for the logit and probit. Test classification accuracy using a sample that was tested produces a quite high classification accuracy rate. Logit in this case is better than the probit because of the level of classification accuracy of $77.89 \%$, compared with $71.58 \%$ using probit.

Table 3. Test the accuracy of classification: Logit Model (in sample)

\begin{tabular}{|c|c|c|c|}
\hline \multirow[b]{2}{*}{ Observed } & Pred & & \multirow{3}{*}{$\begin{array}{c}\text { Percentage } \\
\text { correct }\end{array}$} \\
\hline & \multicolumn{2}{|c|}{ FD } & \\
\hline FD & 0 & 1 & \\
\hline 0 & 64 & 0 & 100.00 \\
\hline & 21 & 10 & 32.00 \\
\hline Total percentage correct & & & 77.89 \\
\hline
\end{tabular}

Table 4. Test the accuracy of classification: Probit Model (in sample)

\begin{tabular}{|c|c|c|c|}
\hline \multirow[b]{2}{*}{ Observed } & \multirow{2}{*}{\multicolumn{2}{|c|}{$\begin{array}{c}\text { Predicted } \\
\text { FD }\end{array}$}} & \multirow{3}{*}{$\begin{array}{c}\text { Percentage } \\
\text { correct }\end{array}$} \\
\hline & & & \\
\hline FD & 0 & 1 & \\
\hline 0 & 64 & 0 & 100.00 \\
\hline & 27 & 4 & 12.90 \\
\hline Total percentage correct & & & 71.58 \\
\hline
\end{tabular}

\section{Out sample}

To see whether the levels of accuracy of classification are consistent on an untested sample, the next model of the regression equation applied to the remaining samples were not tested a total of 11 samples, consisting of five healthy companies (0) and six unhealthy companies (1). The results are presented in tables 5 and 6 .

Table 5. Test the accuracy of classifycation: Logit Model (out sample)

\begin{tabular}{|c|c|c|c|}
\hline \multirow[b]{2}{*}{ Observed } & Pred & & \multirow{3}{*}{$\begin{array}{c}\text { Percentage } \\
\text { correct }\end{array}$} \\
\hline & \multicolumn{2}{|c|}{ FD } & \\
\hline FD & 0 & 1 & \\
\hline 0 & 5 & 0 & 100.00 \\
\hline & 5 & 1 & 16.67 \\
\hline Total percentage correct & & & 54.55 \\
\hline
\end{tabular}

Table 6. Test the accuracy of classification: Probit Model (out sample)

\begin{tabular}{|c|c|c|c|}
\hline \multirow[b]{2}{*}{ Observed } & Pred & & \multirow{3}{*}{$\begin{array}{c}\text { Percentage } \\
\text { correct }\end{array}$} \\
\hline & \multicolumn{2}{|c|}{ FD } & \\
\hline FD & 0 & 1 & \\
\hline 0 & 5 & 0 & 100.00 \\
\hline & 6 & 0 & 0.00 \\
\hline Total percentage correct & & & 45.55 \\
\hline
\end{tabular}

The results prove that the accuracy of the classification of the out samples lower than in samples tested. The small of data of not tested samples, likely contribute to the relatively low accuracy. However, both the accuracy test results confirm that the logit models are superior to the probit model, with the higher percentage classification of accuracy.

\section{CONCLUSIONS}

The main objective of this research is to prove the contribution of GCG to predict company's financial distress. The results show that GCG and other three variables control i.e DTA, CR and company category do not prove significantly to predict the probability of companies experiencing financial difficulties. NPM is the only variable that proved significantly distinguishing healthy firms and distress.

In general, logit and probit models do not result in different conclusions. Both models confirm the goodness of fit of models and the results of hypothesis testing. In terms of classification accuracy, logit model proves more accurate predictions than the probit models. Therefore, this result suggests that logit model is superior than the probit model and better to consider using of the logit model in the next research. 
Data to predict financial distress only one year before distress occurred and not compared with two or three year before, could potentially limit an adequate explanation. Industrial sector selected based on the availability of data may not be representative enough to infer the real condition how the variables hypothesized actually influence the possibility of financial distress.

\section{REFFERENCE}

Almilia, L. S. and Kristijadi. (2003). Financial Ratio Analysis To Predict Financial Distress Conditions in Manufacturing Company in Jakarta Stock Exchange. JAAI, 7(2), 183-210.

Almilia, Luciana S. (2004). Analysis of Factors Affecting Financial Condition Distress of Listed Company in Jakarta Stock Exchange Analisis. Jurnal Riset Akuntasi Indonesia, $7(1), 1-22$.

Ashbaugh, H., Collins, D., and LaFond, R. (2004). Corporate Governance and the Cost of Equity Capital. Working Paper, 1-54.

Bastian, I. dan Suhardjono (2006). Accountancy of Bank, Book 2, $1^{\text {st }}$ Edition, Jakarta: Salemba Empat.

Black, B., Jang, H., and Woochang, K. (2003). Does Corporate Governance Affect Firm Value? Evidence from Korea. Working paper, 1-31.

Beasly, M. S. (1996). An Empirical Analysis of the Relation between the Board of Director Composition and Financial Statement Fraud. The Accounting Review, 71(4), 443-465.

Bhojraj, S. and Sengupta, P. (2003). Effect of Corporate Governance on Bond Ratings and Yields: The Role of Institutional Investors and the Outside Directors. The Journal of Business, 76, 455-475.

Brigham, E. F. and Daves, P. R. (2003). Intermediete Financial Management. Eight Edition. USA: Thomson. South-Western

Byun, H., Kwak, S., and Hwang, L. (2008). The Implied Cost of Equity Capital and Corporate. Asia-Pacific Journal of Financial Studies, 37 (1), 139-184

Coombes, P. and Watson, M. (2000). Three Surveys on Corporate Governance. The McKinsey Quarterly, 4, 74-77.

Darmawati, D., Komsiyah, dan Rahayu, R. G. (2004). The Relationship of Corporate Governance and Financial Performance. Simposium Nasional Akuntansi VII.
DP. E. N. (2007). The Influence of Corporate Governance Implementation to the Company's Financial Distress: An Empirical Study. Jurnal Bisnis dan Akuntansi, 9(1), 88108.

Daily, C. M. and Dalton, D. R. (1994). Bankruptcy and Corporate Governance: The Impactof Board Composition and Structure. Academy of Management Journal, 37(6), 1603-1618.

Elloumi, F. and Gueyie, J. (2001). CEO Compensation, IOS and the Role of Corporate Governance. Corporate Governance, 1(2), 23-33.

Emery, D. R., Finnerty, J. D. and Stowe, J. D. (2007). Corporate financial management (3rd ed.). USA: Prentice Hall.

Fich, E. M. and Slezak, S. L. (2008). Can Corporate Governance Save Distressed Firms From Bankruptcy? An Empirical Analysis. Rev Quant Finan Acc, 30, 225-251.

Gitman, Lawrence J. (2003). Principles of Managerial Finance, Tenth Edition, San Fransisco: Addison Wesley

Gompers, P., Ishi, J. L., and Metrick, A. (2003), Corporate Governance and Equity Prices, Quarterly Journal of Economics, 118, 107-155.

Gujarati, N. D. (2004), Basic Econometrics, $3^{\text {rd }}$ edition, McGraw Hill International editions

Hofer, C. W. (1980). Turnaround Strategies. Journal of Business Strategy, 1, 19-31.

Huang, H. and Zhao, J. (2008). Relationship between Corporate Governance and Financial Distress: An Empirical Study of Distressed Companies in China. International Journal of Management, 25(3). 654-778.

Iramani. (2008). Predicting Model of Financial Distress for Indonesia Listed Companies. Jurnal Aplikasi Manajemen, 6(1).

Morck, R., Shleifer, A., and Vishny, R. W. (1988). Management Ownership and Market Valuation an Empirical Analysis. Journal of Financial Economics, 20, 293-315.

Platt, H. D. and Platt, M. B. (2002). Predicting Corporate Financial Distress: Reflections on Choice-Based Sample Bias. Journal of Economics and Finance, 26(2), 184-199.

Ross, W. J. (2003). Fundamental of Corporate Finance. McGraw Hill.

Sengupta, R. and Faccio, M. (2011). Corporate Response to Distress: Evidence from the Asian Financial Crisis. Federal Reserve Bank of St.Louis Review, 93(2), 127-154. 
Shleifer, A. and Vishny, R. (1997). Survey of Corporate Governance. Journal of Finance, 52, 737-783.

Sulistyanto, H. S. dan Prapti M. S. (2003). Good Corporate Governance: Could it increase social trust?. Ekonomi \& Bisnis-Ekobis, 4(1).

Supatmi. (2007). Corporate Governance and Company's Performance. Jurnal Bisnis dan Ekonomi, 14.

Ward, T. J. and Foster, B. P. (1997). A Note on Selecting a Response Measure for Financial Distress. Journal of Business Finance and Accounting, 24, 78-869.
Widarjo, W. dan Setiawan, D. (2009), The Influence of Financial ratio on Financial Distress in Autumotive Companies, Jurnal Bisnis dan Akuntansi, 11(2), 107-119.

Whitaker, R. B. (1999). The Early Stages of Financial Distress. Journal of Economics and Finance, 23, 123-133.

Yin, H. Y. and Tsui, S. L. (2004). Corporate Governance and Financial Distress: Evidence from Taiwan. Corporate Governance: An International Review, 12(93), 378-388. 